\section{PENERAPAN PEMAKAIAN BAYCHROME -2420 SEBAGAI BAHAN PENYAMAK KROM PADA KULIT DOMBA/KAMBING (WET BLUE)}

Oleh : Muchtar Lutfie, Hernadi Surip, Esti Rahayu, Heru Budi Susanto, Karyono

\section{ABSTRACT}

The objective of this research was to know the shrinked temperature of wet blue from goat an sheep skins that tamed by baychrome 2420 , and for know amount of $\mathrm{Cr}_{2} \mathrm{O}$, was absorbed and axpelled. It skins that tanned by baychrome 2420 , and for selted) preserved were tanned until wet blue used chromosal wand baychrome 2420 as chrome tanning and the others auxilliary material were Na2S, lime, Oropon $B$ and baychrome 2420 as chrome The results of this research showed that baychrome 2420 can used as $O R, N A C l, H C$ mean of shrinked temperature $100.67^{\circ} \mathrm{C}$

mean of $\mathrm{Cr}_{2} \mathrm{O}_{3}$, content $3,99 \%$, and mean of $\mathrm{Cr}_{2} \mathrm{O}_{3}$ residue was expelled $1,54 \mathrm{~g} / \mathrm{l}$.

\section{INTISARI}

Penelitian ini bertujuan untuk mengetahui tingkat kemasakan (shrinked temperature) kuit wet blue Penelinan ini bertujuan dari kulit kambing/domba yang dimasak dengan baychrome 240 , serkambing/domba awet garaman $\mathrm{Cr}_{2} \mathrm{O}_{3}$ yang terserap dan terbuang. Dengan menggunakan 40 lembar kuli kambing/domba awe tgar aman diproses hingga wet blue dengan menggunakan chromosal $B$ dan baychrome 2420 sebagai bahan penyamak krom serta bahan pembantu diantaranya $\mathrm{Na} 2 \mathrm{~S}$, kapur, oropon $\mathrm{OR}_{\mathrm{NaCl}} \mathrm{HCOOH}, \mathrm{H}_{t} \mathrm{SO}_{\text {, }}$ dan lain-lain. Dari hasil penelitian didapatkan bahwa baychrome 2420 dapat digunakan sebagai bahan dan lain-lain. Darih sul $3,99 \%$ serta $\mathrm{Cr}_{2} \mathrm{O}_{3}$ yang terbuang rata-rata $1,54 \mathrm{~g} / \mathrm{l}$.

\section{PENDAHULUAN}

Bahan penyamak Krom $\left(\mathrm{Cr}_{2} \mathrm{O}_{3}\right)$ adalah merupakan salah satu bahan utama yang digunakan oleh industri penyamakan kulit di Indonesia.

Namun pada proses penyamakan tidak semua $\mathrm{Cr}_{2} \mathrm{O}_{3}$ terserap oleh kulit dan sisanya terbuang begitu saja, pada waktu sisa penyamakan dibuang. Hal ini seperti yang dikatakan oleh Paulo de Tarso yang disitasi oleh Sunaryo dan Sutyasmi bahwa krom dalam limbah padat dan telah diencerkan didapatkan $\pm 10 \% \mathrm{Cr}_{2} \mathrm{O}_{3}$ dengan basisitas 30-75\%. Dan pula Muchtar Lutfie pada hasil penelitiannya juga didapatkan kadar $\mathrm{Cr}_{2} \mathrm{O}_{3}$ sebanyak 9,16 gram/liter pada larutan krom.

Sifat dari bahan penyamak krom adalah dengan basisitas rendah, molekul kecil, daya ikat (fixation) kecil dan penetrasinya cepat, ini dibutuhkan pada awal proses penyamakan, dan pada tahapan akhir proses penyamakan krom dibutuhkan daya ikat yang tinggi dan penetrasi yang rendah. Hal ini bisa didapatkan dengan cara menaikkan basisitas.
Dengan majunya teknologi sekarang ini, maka salah satu industri bahan penyamak telah memproduksi salah satu bahan penyamak krom yang namanya Ilaychrom 2420 dengan keistimewaan bahwa penggunaan bahan tersebut tidak membutuhkan kenaikan basisitas, karena pada waktu proses penyamakan berlanesung terjadi penaikan basisitas dengan sendirinya dan akan didapatkan kulit yang masak dengan kadar $\mathrm{Cr}_{2} \mathrm{O}_{3}$ yang terserap juga cukup tinggi, walaupun penggunaannya hanya 6,5\% Baychrom 2420.

Hal ini perlu diteliti untuk ditrapkan pada penyamakan kulit (Wet Blue) dari kulit kambing/domba, agar bisa digunakan sebagai penunjang dalam dunia penyamakan. Kulit wet blue domba/kambing adalah kulit domba/kambing yang disamak dengan bahan penyamak krom, masih dalam keadaan basah dan belum disempurnakan (8).

Bahan penyamak krom memiliki sifat khusus yang berhubungan dengan struktur molekul bahan krom itu sendiri. Bahan penyamak krom yang digunakan adalah garam krom yang mengandung atom-atom krom yang bervalensi tiga. Garam krom ini mampu bereaksi dan membentuk ikatan dengan asam amino dalam struktur protein kolagen yang reaktif. Ikatan yang terbentuk antara krom dan protein kulit disebut ikatan silang. Ikatan silang yang terbentuk selama proses penyamakan akan menyebabkan berubahnya sifat-sifat kulit menjadi tahan terhadap pengaruh fisis atau khemis (5).

Penyamakan krom pada perinsipnya adalah mengusahakan agar kromium oksida dapat masuk dan menempatkan diri dalam kulit pada tahap awal yang pada akhirnya mengadakan ikatan dengan protein kolagen kulit. Dari reaktifitas zat penyamak krom dengan protein kolagen pada kulitt sangat rendah. Hal ini dapat beilangsung dengan baik apabila zat penyamak krom mempunyai basisitas yang cukup rendah tetapi tidak terlalu rendah, karena basisitas yang terlalu rendah menyebabkan sulitnya zat penyamak untuk tetap berada diserat-serat kulit atau reaktifitasnya sangat rendah (6).

Pada awal penyamakan biasanya zat penyamak krom mempunyai basisitas $11 \%$ dengan harapan daya ikat cukup rendah, tetapi tetap mampu untuk mengadakan ikatan dengan protein kolagen walaupun sangat lemah. Penyerapan zat penyamak krom in berlangsung selama kulit berputar 1-3 jam dalam drum pada basisitas $33 \%$ dan untuk menghasilkan daya ikat yang tinggi antara penyamak dengan gugus reaktif dari protein kolagen, maka perlu kenaikan basisitas zat penyamak krom. Dilakukan dengan penambahan natrium bikarbonat atau natrium karbonat. Penaikan basisitas ini harus berjalan secara bertahap sampai mencapai basisitas akhir 55-66\% (5). Yang dimaksud basisitas adalah perbandingan antara jumlah atom $\mathrm{OH}$ terikat dengan jumlah maksimum $\mathrm{Cr}$ yang dapat mengikat $\mathrm{OH}$ (dalam prosentase) (4).

Baychrome 2420 adalah suatu bahan penyamak krom yang kadar $\left(\mathrm{Cr}_{2} \mathrm{O}_{3}\right.$ 
nya $=19,5 \%$, yang didalam pemakaian pada penyamakan tidak membutuhkan soda untuk menaikan basisitasnya, karena secara otomatis berubah sendiri sewaktu terjadinya pengikatan kromium pada zat kulit (protein kolagen) dengan mendapat bantuan pemanasan yaitu berlangsung dari $28^{\circ} \mathrm{C}$ sampai dengan $40^{\circ}-45^{\circ} \mathrm{C}$, dengan jumlah putaran selama 10 jam (1).

Graves (1986), juga mengatakan bahwa untuk menaikkan basisitas pada penyamakan krom selain menggunakan soda juga bisa menggunakan cara pemanasan atau dengan air panas, tetapi harus secara perlahan kenaikan temperatur tersebut (3).

Penelitian ini bertujuan untuk mengetahui tingkat kemasakan (Shrengked temperature) kulit wet blue dari kulit kambing-domba yang disamak dengan baychrome 2420 , serta untuk mengetahui jumlah $\mathrm{Cr} 2 \mathrm{O} 3$ yang terserap dan yang terbuang.

\section{MATERI DAN METODA}

\section{MATERI}

1. Kulit

a) Kulit kambing awet garam basah sebanyak 10 lembar.

b) Kulit domba awet garam basah sebanyak 10 lembar.

2. Bahan Penyamak

a) Chromosal B

b) Baychrome 2420

3. Bahan Pembantu Penyamak

$\mathrm{NaCl}$, Sandozin NIL, $\mathrm{HCOOH}$, Oropon Or, $\mathrm{H}_{2} \mathrm{SO}_{4}, \mathrm{Na}_{2} \mathrm{~S}$, dan lain-lain.

4. Peralatan

Drum, pisau, paku, ember, timbangan dan lain-lain.

\section{METODA}

1. Pelaksanaan penelitian

a) Semua kulit diproses dari soaking (perendaman) hingga sampai proses pikel (pengasaman) dengan tata cara proses yang ada pada laboratorium Kelompok Peneliti Proses Penyamakan Kulit, Balai Penelitian Kulit, BBKKP.

b) Dari sejumlah kulit yang tersedia (pickled) diambil 5 lembar kulit domba dan 5 lembar kulit kambing. Dan dilanjutkan pada proses penyamakan dengan menggunakan Chromosal B sebagai bahan penyamaknya. Tata cara penyamakan sesuai dengan yang ada di laboratorium Peneliti Proses Penyamakan Kulit, BPK, BBKKP.

c) Sisa dari kulit tersebut di atas diproses hingga wet blue dengan menggunakan
Baychrome 2420 sebagai bahan penyamaknya dengan tata cara perlakuanya sesuai dengan petunjuk dari sumbernya, yaitu kulit pickle diputar dengan larutan yang terdiri dari :

$20 \%$ air pickle

$6,5 \%$ Baychrome 2420

selama 10 jam dengan temperatur $40^{\circ} \mathrm{C}-45^{\circ} \mathrm{C}$.

Pengujian/Evaluasi

2.1 Uji Fisis

Kulit hasil penelitian diuji suhu kerutnya (Shringked Temperature) dengan menggunakan gliserin sebagai penghantarnya.

\subsection{Uji Kimia}

Kulit hasil penelitian diuji secara kimia untuk mengetahui kadar $\mathrm{Cr}_{2} \mathrm{O}_{3}$ yang didapatkan pada kulit tersebut.

Begitu juga larutan limbahnya diuji secara kimia untuk mengetahui kadar $\mathrm{Cr}_{2} \mathrm{O}_{3}$ yang masih tersisa/terbuang.

2.3. Analisa Data

Hasil pengujian dianalisa secara statistik dengan menggunakan Completely Randomize Design (CRD).

\section{IIASIL. DAN PEMBAHASAN}

I. Uji Fisis

Uji suhu kerut (Shringked Temperature).

Nilai rata-rata hasil uji suhu kerut kelit hasil penelitian dapat dilihat pada tabel 1 , yaitu :

Tabel 1. Nilai rata-rata hasil uji suhu kerut kulit wet blue hasil penelitian.

\begin{tabular}{|l|c|c|}
\hline \multirow{2}{*}{ No. } & \multicolumn{2}{|c|}{ SUHU KERUT KULIT YANG DISAMAK DENGAN } \\
\cline { 2 - 3 } & Chromosal B (C) & Baychrome 2420 (C) \\
\hline 2. & 110 & 105 \\
3. & 107 & 96 \\
4. & 110 & 95 \\
5. & 109 & 108 \\
6. & 112 & 95 \\
rata-rata & 110 & 105 \\
\hline
\end{tabular}

Vol. XII No. 25 Th. $1997 / 1998$ 
(menggunakan gliserin)

Setelah data tersebut di atas dianalisa dengan analisa varians ternyata menunjukkan ada beda sangat nyata $(P \geq 0,01)$.

Dilihat dari rata-rata keseluruhan menunjukkan bahwa kulit tersebut masak karena di atas $100 \mathrm{C}$, namun bila diperhatikan secara cermat hanya kulit wet blue yang disamak dengan Chromosal B saja yang seluruhnya masak karena suhu kerutnya di atas $100^{\circ} \mathrm{C}$. Untuk kulit yang disamak dengan Baychrome 2420 terlihat tidak merata suhu kerutnya, sehingga bila ditinjau dari segi kemasakan untuk persyaratan wet blue (SII. 0067-84), bisa dikategorikan belum masak.

Kulit bisa dinyatakan masak apabila tidak mengkerut/menyusut bila dimasukkan ke dalam air mendidih, seperti halnya yang dikatakan oleh BASF (1982) bahwa suhu kerut Chrome Leather adalah $100^{\circ} \mathrm{C}$. Perbedaan suhu kerut yang terjadi pada wet blue yang disamak dengan Chromosal B dan yang disamak dengan Baychrome 2420 mungkin juga disebabkan oleh perlakuan yang berbeda. Wet blue hasil dari yang disamak dengan Chromosal $\mathrm{B}$ ada perlakuan untuk kenaikan basisitas, dari basisitas rendah ke basisitas tinggi, yaitu untuk Chromosal B dari basisitas $33,3 \%$ menjadi basisitas $50-55 \%$ dengan menggunakan $\mathrm{Na}_{2} \mathrm{CO}$ sebanyak 2,14 gram setiap kenaikan $1 \%$ basisitas untuk 100 gram $\mathrm{Cr}_{2} \mathrm{O}_{3}$ (Jayusman, 1981).

Dengan adanya penyamakan yang diawali dengan basisitas rendah dan diakhiri dengan basisitas tinggi maka akan didapatkan penyamakan yang lebih sempurna, sedangkan kulit wet blue yang disamak dengan Baychrome 2420 hanya mengandalkan perubahan panas (temperature) pada saat penyamakan itu berlangsung, sedangkan tingkat basisitasnya di sini tidak diketahui karena memang tidak disebutkan.

Graves (1986) memang mengatakan bahwa penaikan basisitas pada penyamakan krom bisa dilaksanakan dengan cara pemanasan, namun perlakuan ini ada efek negatifnya, yaitu bila terdapat kulit yang tingkat penetrasinya rendah atau tidak sama maka akan didapatkan kesempurnaan yang berbeda pula, sebab begitu terjadi pemanasan maka penetrasi langsung berhenti dan yang berlangsung adalah fiksasinya atau pengikatan yang ada di dalam kulit hasil penetrasi, sedangkan sisanya yang berada di luar terjadi pengendapan, baik mengendap dilarutan atau dipermukaan kulit.

\section{Uji Kimia}

2.1 Kadar $\mathrm{Cr} 2 \mathrm{O} 3$ yang didapatkan pada kulit wet blue hasi penelitian dapat dilihat pada tabel 2, yaitu

Iabel 2. Nilai rata-rata hasil uji $\mathrm{Cr}_{2} \mathrm{O}_{3}$ pada kulit wet blue hasil penelitian.

\begin{tabular}{|l|c|c|}
\hline No & Kadar $\mathrm{Cr}_{2} \mathrm{O}_{3}$ pada Wet Blue yang disamak dengan \\
\hline 1 & Chromosal B & Baychrome 2420 \\
\hline 2. & 5,18 & 3,98 \\
1. & 5,21 & 3,93 \\
4 & 5,37 & 4,17 \\
5 & 4,27 & 3,79 \\
6. & 5,02 & 4,11 \\
rata-rata & 5,40 & 3,96 \\
& 5,075 & 3,99 \\
\hline
\end{tabular}

Setelah data-data tersebut di atas dianalisa dengan analisa varian's ternyata menunjukkan ada beda sangat nyata $(\mathrm{P} \geq 0,01)$.

Dilihat dari angka yang didapatkan semuanya memenuhi persyaratan pada S1I. 0067-84. Mutu dan Cara Uji Kulit Domba dan atau Kambing Krom IIasah. Pada Standart Industri Indonesia (SII) tersebut persyaratan adalah minimal $2,5 \% \mathrm{Cr}_{2} \mathrm{O}_{3}$.

Perbedaan yang terjadi adalah disebabkan karena kadar $\mathrm{Cr}_{2} \mathrm{O}_{3}$ yang dikandung oleh bahan penyamak tersebut berbeda, yaitu Chromosal B kandungan $\mathrm{Cr}_{2} \mathrm{O}_{3}$ adalah $26 \%$ sedangkan Baychrome 2420 hanya mengandung $19,5 \% \mathrm{Cr}_{2} \mathrm{O}_{3}$ dan jumlah pemakaiannya juga berbeda, yaitu untuk Chromosal B sebanyak 10\% sedangkan Baychrome 2420 hanya sebanyak $6.5 \%$

Dari kandungan yang berbeda dan jumlah pemakaian yang berbeda tentunya kadar $\mathrm{Cr}_{2} \mathrm{O}_{3}$ yang didapatkan pada wet blue hasil penelitian tersebut juga akan berbeda seperti pada tabel 2 tersebut di atas.

Namun seperti yang dikatakan tersebut di atas bahwa wet blue hasil penelitian memenuhi persyaratan SII 0067-84, sehinggadapat dikatakan behwa Baychrome 2420 bisa dimanfaatkan, dan ini bila ditinjau dari segi ekonomi terdapat penghematan bahan kimia dan tentunya berpengaruh pula pada kurs pembiayaan pengolahan

Bila dilihat dari tabel 2 yang menunjukkan bahwa penggunaan $6,5 \%$ Baychrome 2420 mendapatkan hasil wet blue yang rata-rata mengandung 
$3,99 \% \mathrm{Cr}_{2} \mathrm{O}_{3}$, dan bila diperhitungkan dengan dasar tersebut maka sangat memungkinkan penggunaan Baychrome 2420 diturunkan/dikecilkan menjadi $5 \%$ yang nanti tentunya menghasilkan wet blue yang mempunyai kandungan Cr2O3 sebanyak 3,06\%, yang berarti masih memenuhi persyaratan SII. 006784.

2.2 Kadar $\mathrm{Cr} 2 \mathrm{O} 3$ yang terdapat pada limbah yang dibuang.

Nilai rata-rata dari hasil uji kadar $\mathrm{Cr} 2 \mathrm{O} 3$ yang terdapat pada larutan yang dibuang dapat dilihat pada tabel 3 , yaitu :

\begin{tabular}{|l|c|c|}
\hline No. & \multicolumn{2}{|c|}{ Bahan Penyamak (gram/liter) } \\
\hline & Chromosal B & Baychrome 2420 \\
\hline 1. & 8,27 & 1,55 \\
2. & 8,24 & 1,45 \\
3. & 8,24 & 1,62 \\
rata-rata & 8,25 & 1,54 \\
\hline
\end{tabular}

Data-data tersebut diatas setelah dianalisa dengan analisa Varian's ternyata didapatkan ada beda sangat nyata $(P \geq 0,01)$.

Dilihat dari nilai rata-rata yang didapatkan ternyata kesemuanya diatas dari ambang batas yang dipersyaratkan untuk yang dibuang.

Persyaratan limbah krom untuk kadar $\mathrm{Cr}_{2} \mathrm{O}_{3}$ adalah harus dibawah $1 \mathrm{~g} / \mathrm{l}$. Oleh karena itulah maka perlu adanya penanganan atau pengolahan limbah tersebut agar limbah yang dibuang memenuhi persyaratan.

Terjadinya perbedaan yang sangat nyata antara limbah dari Chromosal B dengan limbah dari Baychrome 2420 ini tentunya adalah akibat dari perbedaan kandungan $\mathrm{Cr}_{2} \mathrm{O}_{3}$ pada bahan penyamak tersebut, yaitu Chromosal $\mathrm{B}=26 \% \mathrm{Cr}_{2} \mathrm{O}_{3}$ sedangkan Baychrome $2420=19,5 \% \mathrm{Cr}_{2} \mathrm{O}_{3}$, serta juga akibat perbedaan jumlah pemakaiannya, yaitu untuk wet blue yang dari samakan Chromosal B penggunaannya 10\% dari berat bloten sedangkan yang menggunakan Baychrome 2420 adalah sebanyak 6,5\% dari berat blotennya. Maka tentunya akibat dari perbedaan inilah yang menyebabkan sisa $\mathrm{Cr}_{2} \mathrm{O}_{3}$ yang terdapat pada larutan limbah berbeda.

Perbedaan ini dapat lebih dipertajam lagi apabila penggunaan Baychrome 2420 diperkecil menjadi 5\% seperti yang disebutkan diatas, dengan harapan wet blue yang dihasilkan masih memenuhi persyaratan SII. 0067-84, dan kadar $\mathrm{Cr}_{2} \mathrm{O}_{3}$ yang terdapat didalam limbah tentunya juga menjadi turun, yaitu $\pm 1,18 \%$ dan angka ini mendekati persyaratan limbah krom $(1 \mathrm{~g} / \mathrm{l})$ yang tentunya penanganan limbahnya lebih mudah bila dibandingkan dengan pemakaian Chromosal $\mathrm{B}$, yang kadar $\mathrm{Cr}_{2} \mathrm{O}_{3}$ dalam air limbahnya masih tinggi.

\section{NITUP}

\section{KISIMPULAN}

+ Dilihat dari data yang didapatkan maka dapat disimpulkan bahwa Baychrome 2420 bisa digunakan sebagai bahan penyamak krom dengan menghasilkan wet blue yang mengandung $\mathrm{Cr} 2 \mathrm{O} 3$ sebanyak $\pm 3,99 \%$, dan rata-rata suhu kerutnya $100,67^{\prime} \mathrm{C}$, serta $\mathrm{Cr} 2 \mathrm{O} 3$ yang terbuang pada limbahnya adalah ratarata $1,54 \mathrm{~g} / 1$.

* Dengan menggunakan Baychrome 2420 bisa didapatkan penghematan bahan kimia dan juga dapat menghasilkan limbah yang dibuang dapat mendekat persyaratan yang diperkenankan, sehingga penanganan limbahnya lebih mudah dilaksanakan, dengan kata lain hal ini dapat dikatakan lebih ekonomis.

\section{SARAN-SARAN}

IIila kita menggunakan Baychrome 2420 sebagai bahan krom pada penyamakan kulit, maka hendaklah drum yang dipergunakan memiliki:

+ Pengaturan waktu pemutaran yang baik

+ Pengaturan suhu/temperatur yang baik

+ Pengaturan RPM yang baik

\section{DAFTAR PUSTAKA}

I IIAYER: Tanning Agent. Bayer AG, Leverkusen, 1994.

2. IIASF : Pocket Bookfor the Leather Technologies. BASF, Aktiengesellschaft, D 6700, Ludwingshafen, Second Edotion, West Germany, 1982.

I Graves RG. : Leather Technology. Nene College, Northampthon NN.37.UJ,UK England, 1986.

4 Jayusman : Pengetahuan Bahan. Yogyakarta, 1981.

4. Mann, I. : Rural Tanning Techniques, Food and Agricultural Organization of the Limited Nation, Rome, 1960.

6 Sharphouse, J.H. : Leather Technician's Hand Book. Leather Product Association, London, 1989.

1. Thorstensen, T.C. : Practical Leather Technology. Robert E. Kriger Publishing Company, Huntington, New York, 1976. 
8.

: Mutu dan Cara Uji Kulit Domba dan atau Kambing Krom Basah. SII, 0067-84. Departemen Perindustrian RI, 1984.

9 : Mutu dan Cara Uji Kulit Sapi Krom Basah (wet blue). SII. $0537-$ 81, Departemen Perindustrian RI, 1981. 